\title{
Science-Based Individual Competitive Research: Analysis of Jargon Used in the Hotel
}

\author{
Nyoman Karina Wedhanti ${ }^{1 *}$, I Gede Budasi ${ }^{1}$ \\ ${ }^{1}$ Universitas Pendidikan Ganesha, Singaraja, Bali, Indonesia \\ *Corresponding author. Email: karina.wedhanti@undiksha.ac.id
}

\begin{abstract}
This study described the final results that was achieved by researchers in qualitative descriptive research which was an effort to identify various jargon used in the hospitality sector, such as Housekeeping, Front Office, Food and Beverage, and HRD in the Lovina Bali. Identification was very much needed because so far, as far as it was observed, the hospitality material books used in various vocational schools throughout Bali have not prepared teaching materials based on the needs analysis used by students learning English for Hotel. Most of the English teaching for the hotel was provided in the form of books that were ready to be sold in bookstores. Teachers had a hard time getting to the specific jargon used in hotels, especially in the important departments that deal directly with guests. Thus, students in colleges who are deployed in hotels have difficulty understanding the jargon used in hotels. To understand it, students need a very long adjustment. Even though, the jargon is definitely needed, however, neither schools nor the hotel industry have provided these jargons to be understood by hotel trainees who are taking job training in hotels throughout Lovina. In this regard, this study aimed at describing a number of jargon needed in hotels and providing a descriptive analysis of the forms and meanings in each of these jargons.
\end{abstract}

Keywords: Jargon, Housekeeping, Front Office, Food and Beverage, HRD, The Lovina Bali

\section{INTRODUCTION}

English for Specific Purposes (ESP) is an approach in teaching that uses English for certain fields of study in line with the needs of the demanded profession. English for Specific Purposes is known by preparing students to use English in an academic, profession, and designing programs based on needs analysis [1]. According to Dudley-Evan, English for Specific Purposes can be classified into two, namely English for Academic Purposes (EAP) and English for Occupational Purposes (EOP) [2].

In this case, hotel is one of the occupations that use jargon as a means of communication. According to Ardiyanto, jargon is a special vocabulary that is used by a group of people to communicate [3]. In addition, Keraf states that jargon is a technical or secret word that has language variations and it can be used in a group of people [4].

In hotel, there are several departments such as Housekeeping, Front Office, Food and Beverage, HRD, Engineering, etc. This department needs communication tools to facilitate their cooperative work. In addition, it is used to express their idea which requires some terms in the communication. As a hospitality agency, hotel departments play an important role in supporting the tourism and business sectors. Based on needs and conditions, the jargon in Housekeeping, Front Office, Food and Beverage, and HRD has been developed.

The fresh graduate workers from vocational high school do not understand the jargon itself. On the other hand, only people who have more knowledge can understand the jargon, as well as graduate from a hospitality or English degree. Therefore, the use of jargon in Housekeeping, Front Office, Food and Beverage, HRD may lead misperceptions and misunderstandings. Thus, researchers are interested to make and observe the used jargon, forms of jargon based on their word formation, and the meaning of the jargon used by the Department of Housekeeping, Front Office, Food and Beverage, HRD.

\section{RESEARCH METHODOLOGY}

This study was conducted in a qualitative research design. Qualitative research was chosen because this research described a situation or phenomenon, in this case the jargon used by the Front Office, Housekeeping, 
Food \& Beverage Service (F\&B Service), Human Resources Department (HRD) at The Lovina Bali which naturally appears in the daily activities of the Front Office, Housekeeping, Food \& Beverage Service (F\&B Service), Human Resources Department (HRD) at The Lovina Bali. This study involved several data collection methods such as: interviews and observation. This study was conducted at The Lovina Bali. The subjects of this research are the Front Office, Housekeeping, Food \& Beverage Service (F\&B Service), Human Resources Department (HRD) at The Lovina Bali. In this study, researchers selected 3 Front Office staffs, 3 Housekeeping staffs, 3 Food \& Beverage Service (F\&B Service) staffs, and 2 Human Resources Department (HRD) staffs as informants. The objects of the study were the jargons used by Front Office, Housekeeping, Food \& Beverage Service (F\&B Service), and Human Resources Department (HRD) at The Lovina Bali. In this study, the main instrument was the researchers themselves assisted by supporting instruments to conduct or collect data. In this study, researchers applied checklists, interview guides, and recording devices.

\section{FINDING AND DISCUSSION}

This study revealed 55 jargons used by waiters in the Food and Beverage department at The Lovina Bali. The hotel Food and Beverage is divided into two divisions, namely Chef and Waiters and Waitress. There were 160 jargons used by the Front Office Department at The Lovina Bali, Singaraja. The front office department of the hotel is divided into four divisions, namely Receptionist, Reservation Officer, and Guest Relations Officer (GRO). Furthermore, 176 jargons were used by the Housekeeping Department at The Lovina Bali. The Housekeeping Department is divided into 6 divisions, namely rooms, public areas, linens, maids, swimming pools, and laundry. Finally, 121 jargons were used by HRD at The Lovina Bali. The jargon had been analyzed based on the word formation process. Each department has different data as follows.

Table 1. The Result of Analysis from Front Office Department

\begin{tabular}{|c|c|c|c|}
\hline Number & Word Formation & Frequency & Percentage \\
\hline 1. & Abbreviation & 23 & $14.4 \%$ \\
\hline 2. & Acronym & 6 & $3.8 \%$ \\
\hline 3. & Affixation & 3 & $1.9 \%$ \\
\hline 4. & Compounding & 9 & $5.6 \%$ \\
\hline 5. & Clipping & 6 & $3.8 \%$ \\
\hline 6. & Borrowing & 2 & $1.2 \%$ \\
\hline 7. & Noun & 26 & $16.2 \%$ \\
\hline 8. & Adjective & 5 & $3.1 \%$ \\
\hline 9. & Verb & 4 & $2.5 \%$ \\
\hline 10. & Noun phrase & 73 & $45.6 \%$ \\
\hline 11. & Prepositional phrase & 1 & $0.6 \%$ \\
\hline 12. & Adverb phrase & 1 & $0.6 \%$ \\
\hline 13. & Adjective phrase & 1 & $0.6 \%$ \\
\hline & Total & 160 & $100 \%$ \\
\hline
\end{tabular}

Table 2. The Result of Analysis from Food and Beverage Department

\begin{tabular}{|c|c|c|c|}
\hline Number & Word Formation & Frequency & Percentage \\
\hline 1. & Abbreviation & 1 & $1.8 \%$ \\
\hline 2. & Borrowing & 4 & $2.2 \%$ \\
\hline 3. & Word & 19 & $34.5 \%$ \\
\hline 4. & Phrase & 6 & $3.3 \%$ \\
\hline 5. & Derivation & 12 & $6.6 \%$ \\
\hline 6. & Compounding & 13 & $7.15 \%$ \\
\hline
\end{tabular}


Table 3. The result of Analysis from House Keeping Department

\begin{tabular}{|c|c|c|c|}
\hline Number & Word Formation & Frequency & $1.70 \%$ \\
\hline 1. & Acronym & 3 & $19.31 \%$ \\
\hline 2. & Abbreviation & 2 & $1.13 \%$ \\
\hline 3. & Borrowing & 1 & $0.56 \%$ \\
\hline 4. & Clipping & 23 & $13.06 \%$ \\
\hline 5. & Compounding & 2 & $1.13 \%$ \\
\hline 6. & Back Formation & 2 & $1.13 \%$ \\
\hline 7. & Derivation & 3 & $1.70 \%$ \\
\hline 8. & Verb & 4 & $2.27 \%$ \\
\hline 9 & Adjective & 32 & $18.18 \%$ \\
\hline 10. & Noun & 6 & $3.40 \%$ \\
\hline 11. & Verb Phrase & 2 & $1.13 \%$ \\
\hline 12. & Adjective Phrase & 62 & $35.22 \%$ \\
\hline 13. & Noun Phrase & 176 & $100 \%$ \\
\hline
\end{tabular}

Table 4. The result of Analysis from Human Resource Department

\begin{tabular}{|c|c|c|c|}
\hline Number & Word Formation & Frequency & Percentage \\
\hline 1 & Acronym & 18 & $6,6 \%$ \\
\hline 2 & Abbreviation & 2 & $1,65 \%$ \\
\hline 3 & Compounding & 5 & $4,13 \%$ \\
\hline 4 & Borrowing & 2 & $1,65 \%$ \\
\hline 5 & Noun & 28 & $22,31 \%$ \\
\hline 6 & Verb & 3 & $1,65 \%$ \\
\hline 7 & Phrase & 83 & $68,8 \%$ \\
\hline
\end{tabular}

\section{CONCLUSIONS AND SUGGESTIONS}

Based on the statement of problems, the conclusions of the study can be seen as follows.

1. Abbreviation as many as $1.8 \%$, Borrowing as many as $2.2 \%$ jargons, Words as much as $34.5 \%$ jargons, Phrase as many as $3.3 \%$ jargons, Derivation as many as $6.6 \%$ jargons, Compounding as many as $7.15 \%$ jargons. Word formation in previous research is phrases ( 2 or $1.9 \%$ ), abbreviations (30 or $28 \%$ ), words (45 or $42 \%$ ), clippings (19 or $10.9 \%$ ), Borrow ( 2 or 1 , $9 \%$ ), combined (2 or $1.9 \%$ ) and acronyms (5 or $4.7 \%)$. In terms of jargon meanings, there are 105 jargon meanings. Previous studies found 45 or $42 \%$ words and the 105 jargons. HRD uses 157 jargons. The House Keeping Department uses 176 jargons, then the Front Office used 160 jargons. The last, Food and Beverage Department uses 55 jargons.

2. Considering the word formation, namely verb, noun, adjective, adverb, and phrase as well as from the 2 word formations that are different from previous research. This study seems to support the theory presented in Chapter 2 and the findings raised in the empirical review. It is because the present study reveals 160 jargons and most jargons around 73 or $45.6 \%$ belongs to phrase. Based on the result of the present and previous study, it can be concluded that jargon is actually used in hospitality, especially in hotels. The present study has found the terms acronym (3 or $1.70 \%$ ), abbreviation (34 or $19.31 \%$ ), borrowing (2 or $1.13 \%$ ), clipping (1 or 0.56 ), compounding (23 or $13,06 \%)$ ), back formation ( 2 or $1.13 \%$ ), derivation ( 2 or $1.13 \%$ ), verb (3 or $1.70 \%$ ), 
adjective (4 or $2.27 \%$ ), noun (32 or $18.18 \%$ ), verb phrases $(6$ or $3.40 \%)$ ), adjective phrases ( 2 or $1.13 \%$ ), and noun phrases (62 or $35.22 \%$ ). Noun phrase is the most common jargon used by the Housekeeping Department at The Lovina Bali because most of the jargon consists of phrases. Meanwhile, nouns are (3 or $1.65 \%$ ), verbs and phrases are (83 or $68.8 \%$ ), acronym is (18 or $6.6 \%$ ), abbreviation is ( 2 or $1.65 \%$ ), compounding is ( 5 or $4.13 \%$ ), borrowing is ( 2 or $1.65 \%)$.

Based on the result of the study, some points can be suggested to the following parties.

1. English Language Education Students

It is suggested to English Language Education students who want to learn material as a reference and also to improve their vocabulary as well as the competence of English Language Education students on linguistic knowledge. (ESP) English for Specific Purposes is related to specific jobs and also interests in various fields of society.

2. Course in Educational English

English Education Course can be used as a reference or material in the ESP course.

3. The researchers are expected to be a resource in the Housekeeping, Front Office, Food and Beverage, and HRD departments at The Lovina Bali to acknowledge their communication system until they will maintain to develop services and accommodation through their communication.

4. Other Researchers

The results of the study can be used as an alternative resources to support other researchers in conducting research. In addition, this study is also useful for English for Specific Purposes (ESP) course.

\section{REFERENCES}

[1] T. Hutchinson and A. Waters, English for Specific Purposes: A learning-centered approach, Glasgow: Bell \& Bain Ltd, 1994.

[2] J. Donough, ESP in Perspective A Practical Guide. London: Collin ELT, 1984.

[3] A. Arief, M. D. Ardiyanto, Pengaruh Pengungkapan Corporate Social Responsibility terhadap Manajemen Laba (Studi Kasus Pada Perusahaan Non Keuangan dan Jasa yang Terdaftar di BEI tahun 2010-2012), Doctoral dissertation, Fakultas Ekonomika dan Bisnis, unpublish, 2014.

[4] G. Keraf, Diksidan Gaya Bahasa, Jakarta: PT Gramedia Pustaka Utama, 2002.
[5] K. Allan, K. Burridge, Forbidden Words:Taboo and the Consoring of Language, Cambridge: Cambridge University Press, 2006.

[6] L. Bauer, English Word-Formation (Cambridge Textbooks in Linguistics), Cambridge: Cambridge University Press, 1983.

[7] G. Booij, The grammar of words: An introduction to linguistic morphology, 2nd edition (Oxford Textbooks in Linguistics), Oxford: Oxford University Press, 2007

[8] J. V. Williamson, A Phonological and Morphological Study of English, 2004.

[9] T. Hutchinson, A. Waters, English for Specific Purposes: A learning-centered approach, Glasgow: Bell \& Bain Ltd, 1994. 